\title{
“Coming Out" as a Faith Changer: \\ Experiences of Faith Declaration for Arabs of a Muslim background who chose to follow a Christian faith
}

Dr. Kathryn Kraft

K.Kraft@uel.ac.uk

\begin{abstract}
:
In the process of conversion, one of the greatest challenges faced by Arab Muslims who choose to follow a Christian faith, is determining how to relate to their birth communities, especially their immediate families. They continue to identify with their family and desire to function within its communal system and expectations, but also desire to be true to their new faith. For most converts in the Middle East, ceasing to adhere to the Islamic creed per se is not an act of apostasy, but declaring that one has left Islam and chosen another faith is, and is seen as an act of rebellion by the community. The process of self-disclosure, or "coming out", is complex, and many converts consider their decision about how to do this to be very important. There are various approaches converts may take, and various ways their families may respond, but one implicitly shared understanding between many converts and their families may be labelled "don't ask, don't tell", whereby converts speak openly about their changed beliefs without explicitly declaring they have converted, and their families respond in kind, deliberately not asking if they have converted, in order to maintain a strong relationships with their loved ones.
\end{abstract}

A fair bit of research has been conducted on why and how Arab Muslims might choose to follow a Christian faith, rather than the Islam of their families (Greenlee 2005, Woodberry 2008), but converts ${ }^{1}$ in the Middle East often report that the greatest challenges in their personal journey happen after they have decided to embrace a different faith. These challenges are underlined by a reality whereby many converts, particularly in the Arab Middle East, come from strongly cohesive families and a religion that provides not only rituals and traditions, but also a well-developed doctrine and a strong sense of community (Mernissi 2002, Lewis 2007, Halverson et al 2011, Zaidi 2011, Zubaida 2009 and 2011). Therefore, one of the most difficult processes post-conversion, with ramifications for all other aspects of adaptation to a new faith identity, is that of "coming out", that is, declaring to a birth community that one is different, having decided to pursue a different faith from that of the family. The process of deciding to "come out", and the way in the process of self-disclosure is approached, has ramifications for arguably all aspects of how converts interact with their families and birth communities.

1 In this study, "convert" refers to individuals born into Muslim homes who have made a faith decision to believe in Christian doctrine. Many such converts may continue to call themselves Muslim even though they no longer adhere wholeheartedly to the Islamic creed (that is, "I testify that there is not God but God, and Muhammad is the prophet of God."), choosing instead to declare loyalty to the "Injil" (New Testament Gospel) and to Jesus, the originator of Christianity. 


\section{Background}

A study of "coming out" is effectively informed by some sociological and anthropological concepts which date back several decades. Sociological literature on deviance, for example, was well-developed in the 1960s (most notably Robert Merton's seminal 1968 work on the topic), but remained largely undeveloped after that, until the past decade. Conversion out of Islam is, as will be described further below, an act of social deviance, that is, a banned or controlled behaviour which is likely to attract punishment or disapproval (Downes and Rock 2003:24-25). Within deviance studies, Goffman's (1963) discussion of stigma is particularly relevant, that is, how deviants are perceived by, and interact with, those around them. More recently, studies of deviance and stigma have been further developed to apply to specific societal issues, such as financial criminality (Baumer and Gustafson 2007, Cao et al 2010, Baron 2011) and alternate sexual orientations (Armstrong 2002, Bybee et al 2009, Carnelly et al 2001). This discussion will draw upon such applications of these theories, applying them to the process of selfdisclosure a convert undergoes with regards to his/her birth community.

The concepts of stigma and deviance are further illuminated by classical anthropological literature on honour and shame, which have been frequently explored in ethnographic studies of Arab and Mediterranean communities. Most Arab Muslim converts come from highly communal cultures, where relationships with others take precedence over one's own priorities (Bourdieu 1965:212). In their communities, honour is rooted in reputation, respect, and self-respect, situating an individual's identity as a member of the group. It guides decisions about how to behave, since the group shares a definition of what is and is not honourable behaviour. It also helps individuals to have a clear sense of their ties and loyalty, in the sense that their own virtuous behaviour reflects well on the entire group. Furthermore, community members are regularly assessing how others perceive them because their identity is rooted in how they are perceived by other members of their community.

Virtuous, or good, behaviour is determined by ascertaining what most respects the group, or the community. It is motivated by a desire to do the very best for the sake of those one loves: Bourdieu quoted Montesquieu (d. 1755) in describing this worldview: "What is forbidden by honour is even more forbidden when the laws do not forbid it; and what honour prescribes, is even more obligatory when the laws do not demand it" (in Bourdieu 1965:230). There is a code of rules which is as often as not unspoken. Each group has its own code: each family, each village, each tribe has some degree of expectations that are understood by all members of the group. Identity as a member of the group is then affirmed through knowledge of these codes (Peristiany 1965, deSilva 2000:25). Indeed, a sense of knowledge about one's community's rules and expectations is very important for converts to feel confident in their role as members of their families and, hence, their own sense of self.

In many communities of the Middle East, decisions are most frequently made according to how any given action will reflect on the individual, his/her kin and his/her community (Baker 2003:24). The expectations of the larger community take precedence over what is best for one individually. Where adherence to the religion of the community is expected, a publicly declared choice of a different religion is therefore deviant, since it will likely be perceived as a decision to respect one's own personal inclinations over the priorities of the community. 
Islam is a religion of individual salvation and judgement, but the religion was birthed into a highly communal culture. For the most part, the Qur'an nor the sayings and practices of the Prophet Muhammad do little to challenge the communal, honour-based nature of society, though it may be argued that neither do they explicitly affirm the importance of communal honour. Nonetheless, as the early teachings of I slam solidified into doctrines, value for community also became a part of Muslim tradition. The umma, that is, the community of Muslim believers, is a key concept in Muslim doctrine. The predominant narratives of Islamic history have been written so as to ensure that its credibility lies in that of the umma, and the political success of the umma in its early years has been used frequently in Muslim discourse to validate the religion and its preeminence. Therefore, community and community honour have been upheld as key values in many Muslim communities, perhaps most notably those of the Arab Middle East (Zeid 1965, Moughrabi 1978, Dodd 1973, Ahmed 2003).

This emphasis on community honour may be contrasted with an evangelical Christian theology which proclaims Christianity as a religion of shame, by holding up events such as Christ's death, as well as the persecution of Christians and their willingness to suffer shame for Christ during the religion's early history. Not all strains of Christianity value shame in this way, but evangelical Christianity often does, and it is to evangelical Christianity that many Arab Muslims choose to convert. Thus, they are leaving a worldview and a community where honour, and their social role in upholding that honour, is of utmost importance. They are replacing it with something which does not overtly provide them with a sense of honour or community, at least not in the same way. This provides them with a degree of freedom: on one hand, they may feel they lack guidance in how to live in a way that is true to their changed loyalties, but on the other hand, they may be able to develop an approach to their home communities which is sensitive to the priorities of their loved once.

\section{Community Interests and Concerns}

In honour-orientated communities, what is not known or stated, is innocuous. The key is perception rather than reality. This stands in contrast to evangelical Christianity, which places a strong emphasis on personal beliefs and provides little guidance on external expression of these beliefs. It is therefore likely that many undergo a private faith change and yet never declare this openly. They do this out of respect for the community, or fear of the community, or some combination of the two. In other instances, there is simply no possible way of communicating this, or at least the convert sees no viable option.

For example, a young Muslim woman felt that her family gave her no choice when she first converted²:

She had several older siblings who converted, causing great family strife. Her father was eager that she not follow in their footsteps and so he restricted her movement. She too did convert, though, but she chose not to announce her decision, out of loyalty to her family. This was an act of respect for her family. Years later, she began living an openly Christian life and has reached the conclusion that her personal development, both emotionally and spiritually, was stunted as a result of her decision earlier in life.

2 All data provided in this article are taken from my PhD research for the University of Bristol, conducted mostly in Lebanon and Egypt during 2004-2007. The bulk of my data is based on in-depth narrative interviews with religious converts from Islam to a Christian faith in the Arab world. 
She did not actually feel that her decision was a choice at all, though; it was merely what was required of her by a father who was already deeply hurt after "losing" several of his children.

Other times, family and loved ones of a convert may blame an outsider so that they do not have to acknowledge that their loved one has shamed them, for example a woman's parents or siblings might blame her husband for her decision. One woman explained:

“My brother called my family [in our home country] and told them. They started talking to me and about me. They would send gifts, nice gifts like sweets and flowers, with Qur'anic verses slipped in them, to try to call me back to Islam. That was about two years ago, and they are still trying to get me to return to Islam. I was particularly scared of my dad - he came over to find out if what my brother had told him was true. I told him it was. He said, [your husband] did that to you, it's not you saying that. To this day, they think my faith is really [my husband's] fault and they don't even really blame me in some ways."

Families often feel some degree of shame even when there is merely a potential conflict in the family or community. However, this may be contained within the family. If shame has already befallen the wider community, though, such as by a stigma like a member's conversion being known, then it is important to remove that shame and its source. Therefore, it is usually easier and preferable to avoid and preempt any public shaming, that is, to prevent any open knowledge of the stigma. Ultimately, exposing a "wrong" act, that is, an act that goes against the community's code, is actually the cause of division. This, then, means that the act of exposing an act is the wrongdoing, rather than the act itself.

To further clarify this concept, perceptions of homosexuality in the West, up until recently in some communities and currently in other communities, provide a useful comparison. Gay tendencies are not stigmatised the way that a public homosexual orientation is. The policy of the U.S. military until recently, that of "don't ask, don't tell" ensured that as long as someone did not self-describe as homosexual, the military was happy to assume that s/he was heterosexual. The wrong act was that of coming out, not of privately acknowledging personal gay tendencies. In highly communal cultures, where perception is even more important, many things are allowable in private that are not accepted if witnessed by others. "Coming-out" is the act of erasing honour, or instilling shame, and is seen as an act of rebellion.

Conversion out of Islam is widely recognised as apostasy from Islam, a crime traditionally considered as warranting the death sentence (Slaughter 1993, Werbner 1996, Ahmed 2003, Garces 2010, Davis 2011). When taken in this framework, apostasy can be conceived as an act of verbalising something that makes the family look bad, which makes the family feel the need to expunge it. Announcing new beliefs is an act of rebellion against the family, and it is actually somewhat irrelevant to faith because faith is individual and what is in the heart does not matter.

If someone does openly convert, it is taken as an insult to Islam. Indeed, apostasy from any religious institution is hurtful to those left behind. Because the umma is so important in Islam, though, the hurt may be even greater. An insult to Islam is taken as an insult to each member of the umma. Furthermore, it is illegal in most Muslim-majority countries to stop being a Muslim, and many Muslims believe that it is utterly impossible to leave Islam. Even if families accept the new beliefs of their loved one, the umma will 
not, and if a convert's family supports him/her open apostasy the family is tainted with the same shame and may be punished accordingly by the wider community or, in some countries, by the political process (for example, through ostracism or intimidation). Open apostasy, therefore, forces people who love the apostate to take sides.

The sense of offence and hurt when someone from a Muslim background in the Middle East adopts a Christian set of beliefs, is exacerbated by the fact that the Arab world, indeed most Muslim countries, have felt offended and wrongly dominated by the Christian West for years (Ahmed 2003:46, Lewis 2007:65, Makris 2007:45). So conversion to Christianity, rather than to a different religion or to atheism, is felt as adding insult to injury. It is taken as an offence and a provocation to the entire community.

\section{Coming out: some key points}

Most Arab Muslims who choose to follow a Christian faith likely desire to uphold their families' honour. In other words, their hesitance to "come out" is a form of self-control out of loyalty to their loved ones. I met many converts during my field research who told me that it was this sense of loyalty that held them back from shouting their new beliefs from the proverbial rooftops in the early days after their conversion. When and if the desire to be loyal is gone, however, converts in the Middle East still feel an obligation and a degree of pressure from their community, knowing that there will be consequences if they deviate openly from that which is expected of them. Leaving Islam is, for almost all people born into a Muslim family, a form of deviance. Islam means submission and loyalty to Islam is assumed; if it fails, the umma is likely to react by imposing control. Self-disclosure, an individual "coming out", especially if done explicitly and publicly, may be seen as an act of selfishness, while staying discreditable may be considered an act of loyalty.

Goffman's conceptualisation of stigma helps shed light on this. Conversion is a stigma in a religiously cohesive community: when most members of a community are Muslim, those few who have left Islam are stigmatised. A person with a stigma can be either "discredited", or "discreditable" (Goffman 1963:57). The stigma of the discredited is already known by those around him/her. The stigma of the discreditable is not yet known - a discreditable person is someone who has a secret. As suggested above, in strongly cohesive communities which value honour, to be discreditable is paramount to not actually having a stigma at all. Again, this is parallel to the LGBT who has not come out: they have a stigma but it has not yet stigmatised them in society because they have kept it a secret.

It is common to tell strangers first. People with whom there is no ongoing relationship, nor any likely future relationship, are least threatening to the stigmatised. In contrast, dear friends and family are the ones whose relationship will be altered forever when someone shares his/her stigma. So a stranger is likely the first to be welcomed into a circle of trust. Similarly converts were happy to tell me, as a foreign visitor in the Middle East, their story, even if few if any of their family or friends knew. Next, stigmatised are most likely to tell those who share the stigma. They find support among others with a similar experience. Family, then, is often the last to know (Goffman 1963:65). Research into the coming-out process among gays has indicated that coming out to parents is the most challenging, but also most definitive, moment in the coming-out process (Hill 2009:353, Carnelley et al 2011). 
As stigmatised decide to whom they will tell what, their lives may become extremely complex, with different people knowing different degrees of information about their identity and stigma:

“I live my life according to circles. This has changed a lot: it has become much more complicated. Every action and type of friendship is a sophisticated situation, as all my friends fit into categories. I do have, for example, one close Muslim friend from before who knows about my background and my faith. People in the closest circle know about my faith. But with most of my friends, I just try to be a witness by my good deeds and actions."

The young man who told me this had just shared the entirety of his conversion experience from Islam to Christianity with me, even though I had only just met him. In contrast, his family knows very little about his change.

It is stressful to have a secret. Research has indicated that keeping a stigmatising secret can affect both mental and physical health among people who may be sexually stigmatised (DiPlacido 1998, Armstrong 2002, Bybee et al 2009: 144). The longer a person keeps a secret, the more s/he has to redevelop his/her mindset and practices to preserve the secret, especially when different people in his/her circles of influence have been made privy to different levels of knowledge about the secret. This stressful mental exercise usually leads to the secret-keeping itself becoming a part of an individual's identity. Therefore, coming out can help a stigmatised person's psychological health and also build solidarity by building relationship with others 'like them', a phrase by which converts often referred to other converts (Armstrong 2002, Hill 2009, Carnelly et al 2011). However, converts often acknowledge that the decision to come out is an individualistic decision, something they are doing for their own good rather than for the sake of their loved once: to some extent it is a decision that their own priorities take precedence over those of the community.

Coming can be done in many ways: it can be done through confrontation, it may take the form of flight from the family home, it may be expressed in choice of spouse (usually choosing a person who shares the stigma as a life partner), or it may happen unintentionally when the stigmatised is found out by a friend or loved one. The stigmatised usually want to maintain control over when/how they come out - the most difficult challenge for them may be the effects of being caught before they are ready to explain themselves. Research among gay men indicates that there is a strong tie between maintaining control of the coming-out process and psychological health (Bybee et al 2009, Hill 2009).

Stigmatised people not only need to be prepared to come out, but they also should be able to explain their stigma in a way that feels right to them and is clear to their families. For example, a convert to a Christian faith might announce, "I 'm now a Christian", or say, "I have read the Bible and fell in love with Jesus", or various other things; when under pressure after being discredited, they will be able to respond to that pressure much more confidently if they can defend their statement and be sure it reflects what they actually believe. They should be confident that it will communicate the true meaning of their conversion to their loved ones.

Baptism and other rituals of faith, such as recitation of a creed or participation in the eucharist, are an important step in the discrediting process. They are often the way in which "coming out" happens. 
Baptism is an act which clearly discredits and applies the stigma of conversion to the newly baptised. It is a point of no return, and it is an act of affiliating to a new community. Other Christian rituals can play a similar role.

Some families, however, may preempt a discrediting in order to avoid shame. If they see it coming they may fight against it. They might try to discourage the potential convert from spending time with Christians or reading a Bible, for example, even forcing a teenage child to stay home and drop out of school, or beating a sibling senseless as a warning. This may indeed slow the stigma of apostasy, and when and if the individual eventually converts, will likely discourage him/her from coming out quickly. On the other hand, I have met individuals who experienced such kinds of pressure and, in their narrative, the family pressure actually often inspired them to consider a new faith even more actively than before. One young woman told me:

“My religion teacher (Islam teacher) noticed that I spent a lot of time with Christians and found out some of what I had been up to and came to talk to my family. He told them that I was spending lots of time with Christians, going to church, reading the Injil, and that I was converting to Christianity. He told me, Look, not even the Christians want anything to do with you! You need to live your Islam, and work to learn the Qur'an, but I said, But I don't believe it! So this caused lots of conflict in my house, and my parents started really pressuring, and I realised that in my home it's better for them to just seem me as a Muslim. I can continue learning about Christianity, but on my own, in secret."

Defiance of her family inspired her to learn more about Christianity; when her teacher and her family began to pressure her, she had not yet actually decided. But, at the same time, her family's reaction did make it clear to her that when she decides she should not announce it.

Indeed, discrediting before a deviant decision has been made can evoke deviance. Obvious suspicion by the family can incite more curiosity and become a self-fulfilling prophecy. This may be particularly true in Arab Muslim communities, where the Bible is well-known as the Christian book, and Jesus and Mary are well-known symbols of the Christian religion. Hence any association with those can evoke a response which can affect the conversion process itself.

Again, when viewed in this perspective, one might conceptualise conversion not as a shift in beliefs, but rather as an act of rebellion against one's community and culture. It is difficult, and in some families perhaps even impossible, to "come out" without disrupting the family; the family then will perceive the disruption as the conversion, rather than the beliefs that caused the disruption in the first place.

\section{What Converts do with regards to their communities' honour}

Some converts remain committed to preserving their communities' honour, while other converts feel that their conversion must entail a rejection of everything about their community, including those things which it holds as honourable but to which the convert may no longer adhere. Most people who have changed faith maintain some degree of family loyalty but also some degree of celebration of freedom from the code of rules they previously were expected to follow. 
Some converts are deeply committed to challenging the ways of their community, including their sense of honour in and of itself: "I care about not caring". Conversion, for them, is in fact as much about challenging the culture, or rebelling, as it is about beliefs. They may not outwardly apostasise, but they will look for opportunities to commit small acts of defiance. One young man explained:

“Many people care about things, but I don't care about a lot of them. I do care about a lot of things also. The issue of caring is really important to me. For example, when I had long hair, often the other guys would make fun of me, like when I'd get in the elevator since we live on the $10^{\text {th }}$ floor. One time I told them, I don't care, it takes nothing from me what you think. Some of them stopped the teasing after that. Anyway, in our neighbourhood everyone cares so much about what people think, that it's important that I don't care and just do my own thing."

Other converts also challenge their communities, even rebelling from tradition, but do so in a way that is intended to demonstrate that their rebellion is actually an honourable way of acting. They may continue following the rules of their community, but protest the claim that their decision to follow a Christian faith is deviant. They may or may not succeed, but they make decisions based on a desire to convince their loved ones that their new faith fits within the community's sense of honour. A woman explained:

"I wanted to be baptised immediately. I saw it as a testimony, and so there would be no sense in doing it in secret. I couldn't do it publicly as long as my parents were opposed to any church involvement, so when they [left the country] I started to make plans for my baptism. But it turned out that the date I had set was two weeks after they returned. Some people told me this was wrong, but I had made up cards inviting colleagues (at this point I was teaching [school]) and pretty much everybody I met."

There are also many converts who seek to win their family over by following all the other rules and avoiding discussion of their conversion. Sometimes they wait to announce their decision until they feel confident their family believes they are honourable people, while other times they win their family's affection back by demonstrating their honour over time. After all, it is also a defining characteristic of an honourable person that $\mathrm{s} /$ he is a visibly good person, who contributes to the community in some noticeable and significant way. So they may work hard at school and career in order to win them over. A woman shared with me the success of her brother in doing this:

He was the first convert in their family. Other siblings converted later on, but at the time he was the only one in the family who had changed faith. When his conversion became known, he was threatened, beaten, expelled from the community, and treated as if dead. Years later, due to his honourable actions toward his brother, he was welcomed back into the family and wider community, and respected by his father as his most beloved son. His Christian identity even became a part of his father's boasts. His father now refers to him affectionately as 'the priest'.

In this narrative, it is worth noting that his sisters never received such consideration for their honourable behaviour; this approach is generally much more plausible for a man than for a woman.

Perhaps the most common approach I identified in my research was "don't ask, don't tell": As long as 
they can pretend it is not there, then it is not there. Family honour is intact, and converts can live according to their conscience in their new faith, including sometimes participating in overtly Christian activities, as long as they do not explicitly declare that they are converts. A woman who has never directly told her parents that she is a convert explained why she opted for this approach:

"At first I argued a lot with them. I was strong and strong-minded, so I argued with them and was very rough with them. We discussed it a lot. It was a decision I made, though, to become softer. I realised that it is more respectful and more important to be peaceful than to argue about the truth. Now we don't talk about it. Because [my older sister] looked through my things, I learned to read the Bible on the Internet... and to not go to meetings if it was a problem for her, or not tell her about what I was doing if it would make her upset. She would ask, Where were you? And at first I would tell her I was at a Christian meeting, but then I learned to just not answer or to not make problems."

With her parents she also avoids confrontation and they avoid confrontation with her, but they talk with her about Christianity and religious history because they know she has studied it. Even so, she still does not tell them she has actually left Islam and selected a different path, and she tries to avoid confronting or challenging them. She has told a few siblings when they decided they, too, wanted to convert. But only then.

\section{Don't Ask, Don't Tell}

Ibn Khaldun wrote (d. 1406): “(Respect for) blood ties is something natural among men, with the rarest exceptions... One feels shame when one's relatives are treated unjustly or attacked, and one wishes to intervene between them and whatever peril or destruction threatens them" (Khaldun 1967:98). Most stigmatised people do in fact want to protect their family out of a sense of loyalty expressed through responsibility and obligation to each other; by choosing not to flaunt or explicitly declare their changed faith, they can do this.

On the part of the family, there needs to be some wilful turning of a blind eye to changed behaviour, if honour is to be preserved. They love their deviant family member, and so they work together to erase the shame. They ignore signs of change, they do not ask questions, and they choose not to suspect that the stigma exists even when all the signs are there. Perhaps it is too obvious to ignore, but they still try to do so, and ask their deviant loved one to refrain from flaunting his/her new identity.

A young man I interviewed insisted that his family does not know about his faith, even though his brother once saw him go to church and his father then confronted him about it.

His father told him to leave home. Two weeks after that his brother met with him and asked him to come back to live at home but not go to church anymore. He agreed and returned home, but he continues to attend church every Sunday morning and to spend much of his free time with Christians. He said that he can do this because his family probably chooses not to suspect. "My mom will sometimes say on Sunday morning, don't come back too late! But we don't talk about it to avoid arguing." 
For families opting for don't ask, don't tell, it is better not to know, because if they do not know then they can pretend it is not there. The convert is often eager to believe that his/her family does not see anything and remains confident that his/her honour in the community is secure, at least until s/he or someone else chooses to reveal their apostasy. This is the unspoken rule of a community where perception is key. Sometimes the signs of stigma are so obvious they seem impossible to ignore, but both deviant and family still choose to ignore them, because once a person is fully discredited, once the conversion is openly announced, the family must react. Their loyalty to their wider community and to the umma means that they will no longer be able to ignore it.

Don't ask, don't tell is often not difficult to achieve in Arab Muslim communities because conversion is unthinkable for so many families. They often cannot even imagine it. After all, they have always believed that Islam is the culmination of religions and Muhammad the last of the Prophets, and they always assumed that no one would ever want to leave this for something more antiquated such as Christianity. Furthermore, legal conversion out of Islam is impossible in most Arab countries. Indeed, converts themselves often explained that it took them a long time learning about the Bible and Jesus until they could even consider converting; usually it took meeting another convert for them to think of it as a possibility, something they could even consider.

So, the fact it is unthinkable is a source of freedom for a convert to continue within his/her community. Much can be said openly: changed values, changed practices, changed language, and changed friends are all present and visible. The only thing that remains hidden is the faith, though an argument could be made that the changed faith is also revealed, simply not verbalised. This woman's narrative illustrates how complete the disclosure may be, and yet allow their families to preserve their sense of honour.

“My family found out because they noticed that something was different. I had been living in the city with this family, and when I came back my language, way of talking, was different. You know the verse in the Injil that says, They will know them by their language? That is what happened. And also, I wasn't praying anymore like a Muslim and things like that, so they could tell I was not like them. So they asked me what happened, and I told them all about the (Christian) family I lived with and how wonderful they were and what good people they were, and I said I became like them. No, I didn't tell them that I was a Christian, that was too hard! But they knew what I meant."

Many converts eventually conclude that not telling, not confronting, is an act of love. A degree of deceit, or at least a careful approach to how they verbalise their change, shows more love and respect for their parents than confronting them with a harsh truth. After one man's parents became ill, and his father went to hospital, he realised that it was better for him to be less confrontational when speaking about his new beliefs:

“I was so excited that I didn't sense the effect it was having on them, how they were hurting. I had become rather aggressive, because to me this is truth, and I needed to tell the truth. I loved them and so wanted to tell them what I'd found, and just expected them to react the same. I should have known, because this is such a big deal, it's my family, and they felt personally affected by my decision, but I was just too excited." 
Different people have different ways of negotiating their apostasy in their communities. Those who have managed to express their change to their families without directly declaring apostasy have been able to move past the stigma and live their lives without such a strong sense that they are carrying a secret, but also without giving up their family or their culture. As their communal heritage taught them, they focus on the needs of the community but they also hold their individual beliefs with integrity.

\section{References:}

Ahmed, Akbar S. 2003. Islam Under Siege. Oxford: Polity Press.

Armstrong, Elizabeth. 2002. Forging Gay Identities. London: The University of Chicago Press.

Baker, William G. 2003. Arabs, Islam, and the Middle East. Dallas: Brown Books Publishing Group.

Baron, Stephen W. 2011. "Street Youths and the Proximate and Contingent Causes of Instrumental Crime: Untangling Anomie Theory." J ustice Quarterly 28: 413-436.

Baumer, Eric P. and Regan Gustafson. 2007. "Social Organization and Instrumental Crime: Assessing the Empirical Validity of Classic and Contemporary Anomie Theories." Criminology 45: 617-663.

Bourdieu, Pierre. 1965. Pp. 191-241 in Honour and Shame, edited by J.G. Peristiany. London: Weidenfeld and Nicolson.

Bybee, Jane A., Eric L. Sullivan, Erich Zielonka, Elizabeth Moes. 2009. “Are Gay Men in Worse Mental Health than Heterosexual Men? The role of Age, Shame and Guilt, and Coming-Out." J ournal of Adult Development 16: 144-154.

Cao, Liqun, Ruohui Zhao, Ling Ren, Jihong "Solomon” Zhao. 2010. "Social Support and Anomie: A Multilevel Analysis of Anomie in Europe and North America." I nternational J ournal of Offender Therapy and Comparative Criminology 54: 625-639.

Carnelley, Katherine B., Erica G. Hepper, Colin Hicks, William Turner. 2011. "Perceived parental reactions to coming out, attachment, and romantic relationship views." Attachment and Human Development 13: 217-236.

Davis, Thomas W.D. 2011. Human Rights in Asia. Surrey: Edward Elgar Publishing.

DiPlacido, Joanne. 1998. "Minority Stress Among Lesbians, Gay Men, and Bisexuals." Pp. 138-159 in Stigma and Sexual Orientation, edited by Gregory M. Herek. London: Sage Publications.

Dodd, Peter C. 1973. "Family Honor and the Forces of Change in Arab Society." International Journal of Middle East Studies 4: 40-54.

Downes, David, and Paul Rock. 2003. Understanding Deviance. Oxford: Oxford University Press.

Garces, Nicholas. 2010. “Islam, Till Death Do You Part: Rethinking Apostasy Laws under Islamic Law and International Legal Obligations." Southwestern Journal of International Law 16: 229-264.

Goffman, Erving. 1963. Stigma. London: Penguin Books.

Greenlee, David H., ed. 2005. From the Straight Path to the Narrow Way. Milton Keynes, Bucks: Authentic.

Halverson, Jeffrey R., H.L. Goodall J r., Steven R. Corman. 2011. Master Narratives of Islamist Extremism. New York: Palgrave MacMillan.

Hill, Natalie L. 2009. "Affirmative Practice and Alternative Sexual Orientations: Helping Clients Navigate the Coming Out Process." Clinical Social Work Journal 37: 346-356.

Khaldun, Ibn. 1967. The Muqaddimah. Chichester, W. Sussex: Princeton University Press.

Lewis, Philip. 2007. Young, British and Muslim. London: Continuum. 
Makris, G.P. 2007. Islam in the Middle East: A Living Tradition. Oxford: Blackwell Publishing.

Mernissi, Fatema. 2002. Islam and Democracy. Cambridge, MA: Perseus Publishing.

Merton, Robert K. 1968. Social Theory and Social Structure. London: the Free Press.

Moughrabi, Fouad M. 1978. "The Arab Basic Personality: A Critical Survey of the Literature." International Journal of Middle East Studies 9: 99-112.

Peristiany, J.G., ed. 1965. Honour and Shame. London: Weidenfeld and Nicolson.

Slaughter, M.M. 1993. "The Salman Rushdie Affair: Apostasy, Honor, and Freedom of Speech." Virginia Law Review 79: 141-198.

Werbner, Pnina. 1996. "Allegories of Sacred Imperfection: Magic, Hermeneutics, and Passion in the Satanic Verses." Current Anthropology 37: S55-S86.

Woodberry, J. Dudley, ed. 2008. From Seed to Fruit: Global Trends, Fruitful Practices, and Emerging Issues among Muslims. Pasadena CA: William Carey Library.

Zaidi, Ali. 2011. Islam, Modernity, and the Human Sciences. New York: Palgrave MacMillan.

Zeid, Abou A.M. 1965. "Honour and Shame among the Bedouins of Egypt." Pp. 243-259 in Honour and Shame, edited by J.G. Peristiany. London: Weidenfeld and Nicolson.

Zubaida, Sami. 2009. Islam, the People and the State: Political Ideas and Movements in the Middle East, $3^{\text {rd }}$ ed. London: I.B. Taurus.

Zubaida, Sami. 2011. Beyond Islam: A New Understanding of the Middle East. London: I.B. Taurus. 